\title{
A review on organosolv pretreatment of softwood with a focus on enzymatic hydrolysis of cellulose
}

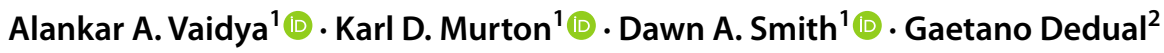

Received: 13 September 2021 / Revised: 16 January 2022 / Accepted: 20 January 2022 / Published online: 8 February 2022

(c) The Author(s) 2022

\begin{abstract}
A clean and efficient fractionation of biomass into cellulose, hemicellulose and lignin streams is a key step in biofuel and biorefinery industries. Lignin-free cellulose and hemicellulose streams can be enzymatically hydrolysed to sugars for fermentation to different biofuels, high value biochemicals and biopolymers. Towards this objective, organosolv pretreatment is the promising strategy to separate lignin from carbohydrates. Scientific information on the organosolv pretreatment using lignocellulosic biomass in general and various organic wastes is available with a focus on lignin separation and its use. Amongst different lignocellulosic biomass, softwood is a challenging feedstock due to recalcitrance towards enzymatic hydrolysis of cellulose. The aim of this review is to describe technical and research efforts on various organosolv processes developed specifically for softwood as a feedstock and how it influences enzymatic hydrolysis of cellulose. Process severity factor, selection of the solvent and choice of a catalyst in organosolv process are discussed. The differences in conventional pulping versus organosolv pretreatment and physico-chemical changes that occur in organosolv fractionated cellulose, lignin and hemicellulose are explained. Pilot and demonstration scale organosolv treatment plants and the challenges they face going towards commercialisation, as well as a path to the future growth and advancement in softwood organosolv processes, are discussed.
\end{abstract}

Keywords Biorefinery $\cdot$ Cellulose $\cdot$ Enzymatic hydrolysis $\cdot$ Organosolv $\cdot$ Pretreatment $\cdot$ Softwood

\section{Introduction}

Non-food lignocellulosic biomass such as crop residues, energy crops and forest waste are the focus of global research in the production of second-generation biofuels and renewable biochemicals [1-3]. Commercial forestry based on softwood is widely spread in temperate and subtropical areas including Chile, Spain, South Africa, New Zealand and Australia [4]. In New Zealand, well-established sustainable softwood plantations are grown on 1.7 million hectares, which is about $7 \%$ of total New Zealand land area [5]. This provides an assured supply of fast-growing softwood for the pulp and paper industry and timber processing for furniture and housing. A considerable portion of waste is generated

Alankar A. Vaidya

alankar.vaidya@ scionresearch.com

1 Scion, Te Papa Tipu Innovation Park, 49 Sala Street, Rotorua 3010, New Zealand

2 Futurity Bio-Ventures Ltd. 12 Oneroa Road, Wainui 4010, Gisborne, New Zealand during the harvesting of the trees (such as twigs, branches, offcuts and stumps) and timber processing (such as wood chips and sawdust) that could be used as a feedstock for the production of biofuels and biochemicals [4]. One of the most promising approaches involve using enzymes to hydrolyse carbohydrate polymers to monomeric sugars and then fermenting these sugars to the various bio-based products [6]. Depending on the quality of the isolated lignin, it can be directly used for supplying energy or chemically/biochemically processed to get value-added products [7-9].

A typical composition of softwood on a weight basis is as follows: cellulose $42-45 \%$, hemicelluloses $21-24 \%$, lignin $25-30 \%$, extractives $1-10 \%$ and less than $1 \%$ inorganic compounds. Softwood cellulose is a linear polymer of D-glucose units with a high degree of polymerisation ( $\mathrm{DP} \approx 10,000)$, high ordered structure and partially crystalline in nature. It is intertwined with hemicellulose, which is a short and branched structure consisting of partially acetylated glucomannans and galactoglucomannans with xylose and arabinose present in smaller amounts. Softwood lignin is mainly made from coniferyl alcohol 
as a precursor. It is a guaiacyl- and $p$-hydroxyphenyl-type lignin having lower methoxy content, being highly condensed, having crystalline and being resistant to deconstruction. Extractives are organic compounds including terpenes, aliphatic acids, alcohols, alkaloid, phenolics, gums, resins, flavonoids and essential oils which can have influence on the properties and processing quality of the softwood [10-13].

Different components of the softwood can be used as a feedstock in the production of biofuels and biochemicals, provided clean and efficient fractionation of each component into separate streams is achieved. Many pretreatments such as physical, biological, physico-chemical, chemical and combinations have been developed $[12,14]$ for fractionating softwood. However, not many of them can efficiently fractionate cellulose, hemicellulose and lignin as a separate processable and value-added stream. An effective pretreatment that can remove lignin and hemicelluloses encasing the cellulose microfibrils, and make the cellulose more accessible to the enzymes, is critical to the sugar yields during enzymatic hydrolysis $[6,15]$. Towards this the most promising pretreatment is the organosolv process originally developed to separate lignin in high purity from carbohydrates [16]. This pretreatment was proposed as early as 1931 by Kleinert and $v$. Tayenthal for the delignification of pulp where lignin is extracted using organic solvents or aqueous solutions $[17,18]$. Main advantages of organosolv pretreatment over other pretreatments are high yield of enzymatic hydrolysable cellulosic pulp and generation of pure lignin; both are potential feedstocks for biorefinery. The other advantage is easy recovery and reuse of organic solvents at the end of organosolv process $[8,9,19]$. Organosolv pretreatment have some disadvantages such as high cost of organic solvents and high capital investment in the equipment due to highly volatile nature of many organic solvents [20].

There are recent reviews available on organosolv pretreatment of lignocellulosic biomass in general [21-27]; however, only one review by Nitsos et al. (2018) focus on organosolv pretreatment of softwood. Here, we aim to fill this gap in describing different organosolv pretreatment strategies specifically for softwood as a feedstock, with an emphasis on improving enzymatic hydrolysis of cellulose into a glucose stream. The specific objectives of this review are to (1) discuss the basic organosolv process and give guidelines on selection of a particular solvent and catalyst with a focus on softwood as a feedstock; (2) describe the effect of different organosolv treatments on the enzymatic hydrolysis of softwood; (3) explain the physico-chemical changes in cellulose, lignin and hemicellulose after organosolv treatment; and (4) discuss pilot and demonstration scale plants and the challenges faced towards commercialisation of organosolv pretreatment of softwood. Discussion on individual organosolv steps, reaction mechanism and factors influencing organosolv process is out of scope as this information is widely available in the literature.

\section{Organosolv pretreatment}

A representative organosolv process is schematically shown in Fig. 1. Typically, biomass is treated with organic solvents such as aqueous ethanol, acetone, acetic acid, methanol, butanol or glycerol with or without catalyst at high temperatures from 100 to $250{ }^{\circ} \mathrm{C}$, for durations ranging from 30 to 60 min [7, 8, 19, 24, 28-34]. The cellulose-rich pulp is separated by solid-liquid separation using filtration or centrifugation. In spent liquor, both lignin and hemicellulose fractions are dissolved. The lignin is precipitated from the liquor by dilution with water with partially hydrolysed hemicellulose, furans and soluble lignin which remained dissolved in the liquor. Generally, organic solvent is recovered and recycled from the spent liquor.

\subsection{Severity factor}

The severity of the organosolv process is measured as severity factor $\left(S_{0}\right)$ which is a combination of pretreatment reaction time and temperature. This factor is expressed in Eq. 1 originally proposed by Overend et al. (1987) [17].

Severity factor $\left(S_{0}\right)=\log (t \times \exp ((T-100) / 14.75))$

where $t$ is the residence time ( $\min )$ and $T$ is the pretreatment temperature $\left({ }^{\circ} \mathrm{C}\right)$. Equation 1 is modified to include $\mathrm{pH}$ term when organosolv process is performed in the presence of acid/base catalyst such as $\mathrm{H}_{2} \mathrm{SO}_{4}$ or $\mathrm{NaOH}$. This is expressed by combined severity (CS) factor which is a function of time, temperature and $\mathrm{pH}$ (Eq. 2) [23].

Combined severity $=\log \left(\mathrm{t} \times \exp \left(\left(\mathrm{T}-\mathrm{T}_{\text {ref }}\right) / 14.75\right)\right)-\mathrm{pH}$

where $T_{\text {ref }}$ is $100{ }^{\circ} \mathrm{C}, t$ is the residence time (min) and $T$ is the pretreatment temperature $\left({ }^{\circ} \mathrm{C}\right)$. The relationship between pretreatment severity and enzymatic hydrolysis of cellulose depends on the type of reactor used and the scale of the process. Pretreatment studies conducted in different reactor configurations are often difficult to compare even when carried out at similar severity values $[26,35]$. The optimal severity of the organosolv process varies with the type and nature of softwood biomass, solvent and catalyst used in the organosolv process. The severity factor needs to be empirically selected to get good cellulose recovery and improve enzymatic digestibility. A high severity organosolv pretreatment is applied for delignification and removing hemicellulose; however, this results in significant degradation of cellulose and sugars creating enzyme or fermentation inhibitors [27]. 
Fig. 1 Schematic of a general organosolv process

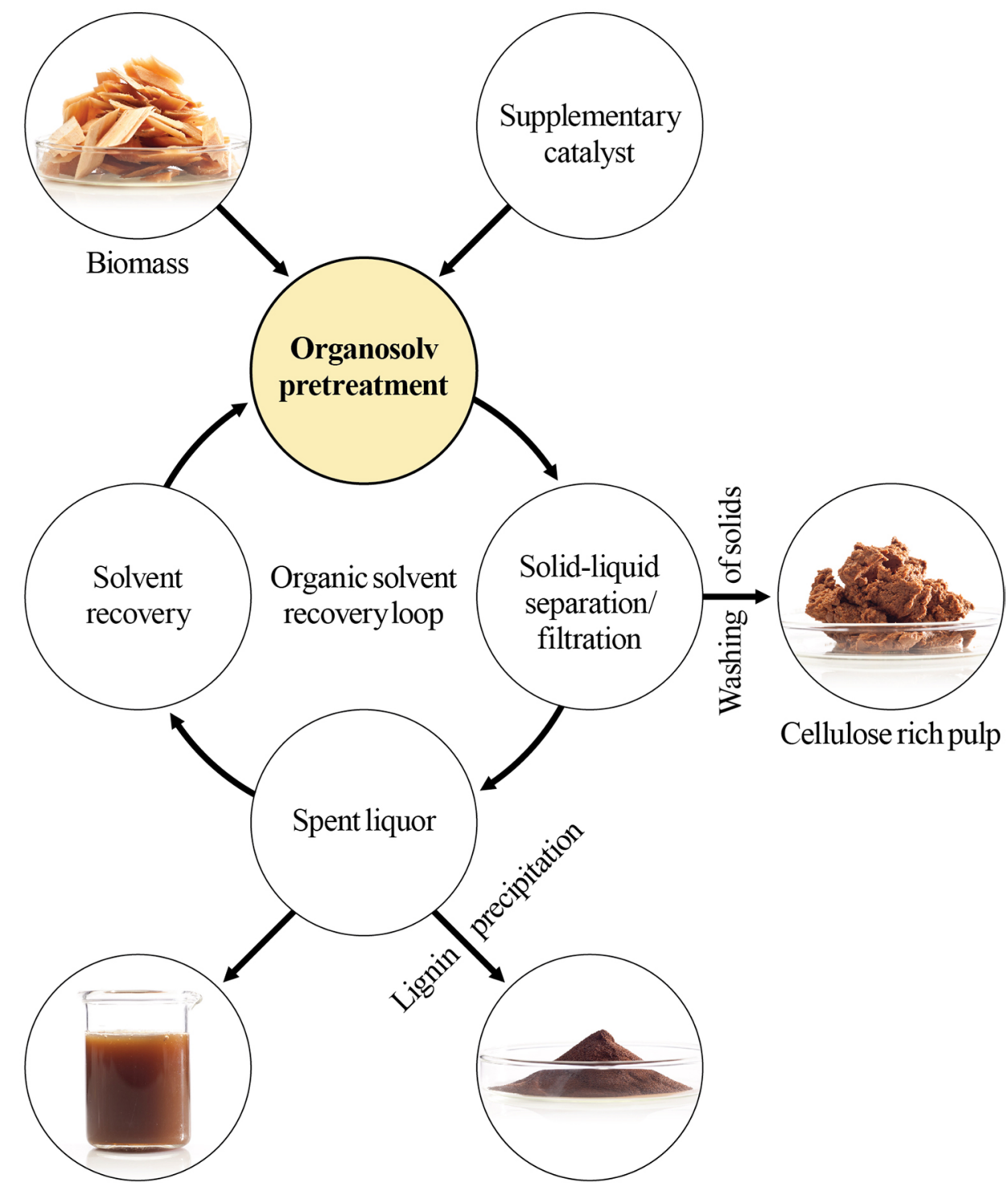

Mono-and oligo-meric hemicellulose+furans

+ soluble lignin

\subsection{Different organic solvents}

The most common solvent used is ethanol, due to its low price, good solubility of lignin, lack of toxicity, miscibility with water and ease of recovery [25, 36-38]. Ethanol in organosolv pretreatment primarily affects the process in two ways: (1) enhancing the impregnation of the softwood by transferring the catalyst or reagent to the lignin, (2) transporting the soluble lignin fragments from the cellular matrix to the bulk liquor solution [39].

Ethanol-organosolv treatment is more efficient for hardwood and herbaceous biomass compared to softwood. Other solvents such as butanol, acetone, ethylene glycol and glycerol were tried for fractionation of softwood. Delignification of southern yellow pine was investigated at $175{ }^{\circ} \mathrm{C}$ with a $50 \%$ water-ethanol and water-butanol system for $80 \mathrm{~min}$. The lignin removal of $16 \%$ for the ethanol and $28 \%$ for the butanol system was reported [40]. The butanol/sulphur dioxide $\left(\mathrm{SO}_{2}\right)$ pretreatment for the mountain beetle-killed lodgepole pine resulted in $82 \%$ and $100 \%$ cellulose hydrolysis in $12 \mathrm{~h}$ and $72 \mathrm{~h}$ respectively. The high severity in butanol pretreatments resulted in the substrate with less hemicellulose, smaller fibre length, increased ratio of large versus small pores, lower DP of cellulose and increased swelling. All these factors contribute to increase in enzymatic hydrolysis of the cellulose with minimum sugar degradation [41]. The use of acetone $(50 \% \mathrm{v} / \mathrm{v})$ in organosolv pretreatment of Pinus radiata D. Don completely solubilised hemicellulose 
and resulted in cellulose hydrolysis of 38-72\% depending on the process severity [28]. The cost of acetone prohibits wide use of this process. The organosolv process can be performed at atmospheric pressure when high-boilingpoint (BP) alcohols such as ethylene glycol $\left(\mathrm{BP}=197{ }^{\circ} \mathrm{C}\right)$ and glycerol $\left(\mathrm{BP}=290^{\circ} \mathrm{C}\right)$ employed as solvents. Different softwoods such as pine, spruce, cedar and Douglas fir were fractionated using dimethyl carbonate-ethylene glycol at $140{ }^{\circ} \mathrm{C}, 40$ min leading to $98 \%$ extraction of monophenolic compounds from lignin and enzymatic cellulose hydrolysis resulted in $85 \%$ glucose yield [42]. Biodiesel side-product glycerol mixed with sodium salts of laurate (20\%) was used as mixed solvent system in organosolv delignification of Japanese cedar and spruce at $250{ }^{\circ} \mathrm{C}$ for $1 \mathrm{~h}$. This resulted in reduction of lignin by almost $27 \%$ in Japanese cedar and $18 \%$ in spruce. Enzymatic hydrolysis of delignified Japanese cedar (9.3\% lignin) gave $0.55-0.67 \mathrm{~g}$ glucose/g cellulose after $72 \mathrm{~h}$. Also, lignin dissolution in glycerol resulted in improved calorific value of recycled glycerol from 20 to $25 \mathrm{MJ} / \mathrm{kg}$ [43]. Alkaline pulping of Pinus sylvestris using glycerol (wood:glycerol $=1: 13.3 \mathrm{w} / \mathrm{w}$ ) as a solvent showed enzymatic hydrolysis of the pulp depends on the pulp composition, and pulp characteristics such as drying of the pulp reduced cellulose conversion [44]. The high cost and high energy consumption for the recovery of ethylene glycol and glycerol limited their use in organosolv processes.

\subsection{Different solubility parameters}

The ability of single solvents to dissolve or swell lignin increases as the cohesive energy density or hydrogen-bonding capacity of the solvents increases and associated solubility parameter (Hildebrand parameter, $\delta 1$ value), approach an estimated value of around $22.5\left(\mathrm{~J} / \mathrm{cm}^{3}\right)^{-1 / 2}$ which is the approximate solubility parameter of extracted wood lignin ( $\delta 2$ value) [45]. If the $\delta 1$ value of the solvent is too dissimilar from the $\delta 2$ value of the lignin, the solvent cannot solubilise lignin or only can solubilise a small fraction of lignin. For example, water has strong hydrogen bonding ability, but its $\delta 1$ value is much higher (47.3), so that lignin is hardly solubilised in water. For polar molecules and mixture of solvents, Hansen and Björkman [46] proposed three different intermolecular interactions such as dispersive $\left(\delta_{\mathrm{D}}\right)$, polar $\left(\delta_{\mathrm{p}}\right)$ and hydrogen bonding $\left(\delta_{\mathrm{H}}\right)$ which will affect solubility of lignin in a solvent or mixture of solvents. However, Hansen solubility parameter alone cannot explain lignin dissolution since the values are used to measure the intermolecular affinity between solvent and lignin but do not account for their intramolecular affinities [47, 48]. The Hildebrand $(\delta 1)$ and Hansen values of different organic solvents commonly used in the organosolv pretreatment of softwood are listed in Table 1, showing ethanol as a good solvent, generally for lignocellulosic biomass. The solubility of lignin in aqueous
Table 1 Comparison of key organic solvents used in the organosolv pretreatment of softwood based on Hildebrand $(\delta 1)$ and Hansen $\left(\delta_{\mathrm{D}}\right.$, $\delta_{\mathrm{p}}$ and $\left.\delta_{\mathrm{H}}\right)$ solubility parameter values. $\delta$ value units are $\left(\mathrm{J} / \mathrm{cm}^{3}\right)^{-1 / 2}$. The Hildebrand $(\delta 1)$ and Hansen solubility values are taken from references [45-48]

\begin{tabular}{lllrr}
\hline Solvent & $\delta 1$ & $\delta_{\mathrm{D}}$ & \multicolumn{1}{c}{$\delta_{\mathrm{p}}$} & $\delta_{\mathrm{H}}$ \\
\hline Diethyl ether & 15.4 & 15 & 2.9 & 4.6 \\
Ethyl acetate & 18.6 & 15.8 & 5.3 & 7.2 \\
Tetrahydrofuran & 20.3 & 16.8 & 5.7 & 8.0 \\
Acetone & 20.5 & 15.5 & 10.4 & 7.0 \\
Extracted wood lignin $^{\mathrm{a}}$ & $22.5(\delta 2)$ & 21.9 & 14.1 & 16.9 \\
n-Butanol $_{\text {n-Propanol }}$ & 23.3 & 16.0 & 5.7 & 15.8 \\
Dimethylformamide & 23.4 & 16.0 & 6.1 & 16.0 \\
Acetic acid & 24.8 & 17.0 & 14.0 & 11.0 \\
Ethanol & 25.8 & 14.5 & 8.0 & 13.5 \\
Dimethyl sulfoxide & 26 & 15.8 & 8.8 & 19.4 \\
Methanol & 27.4 & 18.0 & 16.4 & 10.2 \\
Ethylene glycol & 29.7 & 15.1 & 12.3 & 22.3 \\
Glycerol & 32.1 & 17.0 & 11.0 & 26.0 \\
Water & 33.8 & 17.4 & 12.1 & 29.3 \\
\hline
\end{tabular}

${ }^{\mathrm{a}}$ The extracted lignin is not the same as native lignin

ethanol is significantly affected by ethanol concentration [49]. The optimal ethanol concentration in organosolv pretreatment is usually selected in the range of 50 to $60 \mathrm{wt} \%$ at a softwood loading of 10 to $25 \mathrm{wt} \%$ [10, 25].

\subsection{Organosolv process for pulping versus biomass fractionation for biorefinery}

Traditional paper manufacturing processes such as Kraft and sulphite use hazardous chemicals resulting in wastewater disposal problem; a fraction of cellulose is lost in the liquid stream, and impure and degraded lignin collected in black liquor. Moreover, the cellulose pulp obtained from Kraft and sulphite processes did not respond well to the enzymatic hydrolysis, and recovery of pure lignin from black liquor is cost and energy intensive. To overcome these problems, organosolv process was developed which provided a clean fractionation of lignin and cellulose, both of which can be used as feedstocks in the biorefinery [11]. In the organosolv process, comparative mild chemicals are used which can be recycled and reused creating less hazardous waste. There are distinct differences when applying the organosolv process for paper manufacturing versus to achieve high enzymatic cellulose digestibility. These differences are as follows: (1) Pulping for paper manufacturing requires a high degree of delignification whereas for cellulose digestibility, partial delignification could be sufficient; (2) the pulping process for paper manufacturing is optimised for obtaining a high pulp yield and preserving a good fibre quality, 
while for cellulose digestibility the optimisation is generally approached by increasing cellulose accessibility with a compromise on fibre quality allowing some degradation of cellulose structure [50].

\section{Different organosolv pretreatments applied to softwood}

The basic organosolv pretreatment process involves only ethanol as a solvent without adding any catalyst. This leads to a relatively low delignification yield and lower enzymatic hydrolysis of cellulose to glucose. Therefore, other co-solvents/catalysts are added along with ethanol in the modified organosolv pretreatment. A catalyst in the form of dilute mineral acid such as sulphuric $\left(\mathrm{H}_{2} \mathrm{SO}_{4}\right)$ or hydrochloric $(\mathrm{HCl})(0.1$ to $2.5 \mathrm{wt} \%)$ is often used to accelerate the process and reduce pretreatment time [2, 33, 34, 41, 51]. Different modifications to the basic organosolv pretreatment are outlined in the following sub-sections:

\subsection{Acid-catalysed ethanol organosolv pretreatment}

Softwoods have low concentrations of acetyl groups, which when combined with an inherent recalcitrant nature do not allow self-catalysed reactions to improve the enzymatic digestibility of the organosolv pulp. Hence, addition of an acid catalyst supplements the low natural acidity of the softwood feedstock in the ethanol organosolv process. The glucosidic bonds of hemicelluloses and celluloses are susceptible to the acid catalyst. Acid-catalysed organosolv pretreatment is usually performed at a lower temperature, traditionally below $200{ }^{\circ} \mathrm{C}$ compared to autocatalysed ethanol pretreatment. The acid-catalysed pretreatment is conducted using an inorganic acid such as sulphuric, phosphoric or nitric acid. The most preferred acid is $\mathrm{H}_{2} \mathrm{SO}_{4}$ at a concentration of 0.1 to $2.5 \mathrm{wt} \%$ with residence time and solids loading varying from $30 \mathrm{~min}$ to $1 \mathrm{~h}$ and 5 to $15 \% \mathrm{w} / \mathrm{v}$, respectively [10]. The acid-catalysed ethanol-organosolv process was optimised for ethanol-water content and $\mathrm{H}_{2} \mathrm{SO}_{4}$ concentration using different softwoods. The optimum system (60:40 ethanol-water, $175{ }^{\circ} \mathrm{C}, 0.25 \% \mathrm{H}_{2} \mathrm{SO}_{4}$ ) achieved cellulose yield and purity of $82 \% \pm 3 \%$ and $71 \% \pm 3 \%$, respectively [52]. However, strong inorganic acids have more corrosive effects than organic acids. Thus, some organic acids, such as formic and acetic acid, are chosen as catalysts for use at high process severity. A complete enzymatic hydrolysis of Norway spruce cellulose was achieved using formic acid as a catalyst (maintain $\mathrm{pH} \sim 3.5$ in aqueous phase) under high severity ethanol organosolv process at $63 \mathrm{wt} \%$ ethanol, 170-240 ${ }^{\circ} \mathrm{C}, 90 \mathrm{~min}$ [53]. The acid-catalysed organosolv processes are effective in solubilising hemicellulose but not so effective in removing lignin. After acid-organosolv treatment, the cellulosic pulp requires a wash with dilute alkali or ammonia to remove acetylated or formyl functional groups on cellulose. The enzymatic hydrolysis efficiency of cellulose is compromised if these ester groups are not removed. This was demonstrated in Douglas fir treated with 95\% acetic acid and subsequent enzymatic hydrolysis of the acetylated substrate resulted in a meagre $10 \%$ cellulose conversion versus after complete deacetylation of the substrate resulted in enzymatic cellulose hydrolysis of $60 \%$ [54].

\subsection{Alkaline-catalysed ethanol organosolv pretreatment}

Alkaline catalysis is a selective delignification strategy which also lowers the DP and crystallinity of cellulose. The auto-hydrolysis and dissolution of cellulose and hemicellulose is reduced [14] and swelling of the biomass was improved. In one-step alkaline-organosolv treatment of pine sawdust, using 3\% sodium hydroxide, $45 \%$ ethanol and $150-165{ }^{\circ} \mathrm{C}$ for $120 \mathrm{~min}$ resulted in $91 \%$ removal of lignin without loss of cellulose. Subsequent enzymatic hydrolysis of the cellulose gave almost $90 \%$ conversion [55]. Several alkaline catalysts are used in the ethanol organosolv, including inorganic bases such as sodium hydroxide, potassium hydroxide, calcium hydroxide and some organic amines such as ethyl-, propyl-, butyl-amines and ethylenediamine [27]. Generally, sodium hydroxide is used for low lignin containing substrates such as herbaceous and hardwood biomass whereas calcium hydroxide though expensive is applied to high lignin containing substrates such as softwood. Alkaline catalyst efficiency is dependent on the temperature and retention time of the process. This can range from room temperature to $150-250{ }^{\circ} \mathrm{C}$ and from $30 \mathrm{~min}$ to weeks, respectively [10]. The inorganic base-catalysed process usually generates significant wastewater that requires neutralisation, leading to additional disposal costs.

\subsection{A two-stage combinative organosolv pretreatment}

A two-stage combinative organosolv pretreatment of softwood is an important advancement because of higher efficiency, higher delignification rates and lower production of fermentation inhibitors. The first stage involves a pre-soaking or pre-hydrolysis of biomass with steam or hot water to partly hydrolyse and extract hemicelluloses mainly in the oligomeric form. This reduces the formation of furfural (F) and hydroxymethyl furfural (HMF) in the subsequent organosolv stage. Breaking lignin-hemicellulose bonds in the pre-extraction step enables increased lignin removal in the subsequent organosolv liquor [51, 56]. A care should be taken to prevent repolymerisation and redeposition of 
highly condensed and insoluble lignin on the substrate in the pre-extraction step. This redeposited condensed lignin will impair the extraction of residual lignin in the subsequent organosolv step. It was observed that addition of carbonium ion scavengers such as 2-naphthol, cresol and hydroquinone can reduce repolymerisation of lignin. One of the initial examples of two-stage organosolv pretreatment was performed on Pinus sp. when first step hot water autohydrolysis $\left(150-180{ }^{\circ} \mathrm{C}, 30-60 \mathrm{~min}\right)$ resulted in hemicellulose extraction in autohydrolysate liquor followed by second step acid-catalysed organosolv (50-75\% v/v ethanol, $1 \mathrm{wt} \% \mathrm{H}_{2} \mathrm{SO}_{4}, 180-185{ }^{\circ} \mathrm{C}, 60-75 \mathrm{~min}$ ) leads to delignification. Overall, this improved the fractionation of components with increased enzymatic hydrolysis of the cellulose fraction $[4,10,51]$. In another study, pre-extraction of hemicelluloses before a mild thermo-mechanical pretreatment increased enzymatic hydrolysis of the Pinus radiata [15]. Moreria et al. [56] reported a three-stage organosolv pretreatment of Pinus pinaster; the first step was autohydrolysis $\left(160-180{ }^{\circ} \mathrm{C}, 30\right.$ and $\left.60 \mathrm{~min}\right)$ when $17 \mathrm{wt} \%$ of the original biomass mostly hemicellulose extracted in autohydrolysate liquor. The second step soda-ethanol organosolv $\left(170{ }^{\circ} \mathrm{C}\right.$, $90 \mathrm{~min}$, ethanol 15-35 wt \%) followed by the third step acid lignin precipitation which resulted in $92 \mathrm{wt} \%$ cellulosic pulp and $98 \%$ lignin precipitated at the end of the third step.

\subsection{Other organosolv pretreatments}

Ethanol organosolv pretreatment using inorganic salts as catalysts can be environmentally friendly as the salts are less corrosive to the corresponding acids and can be recycled easily. The wastewater streams generated from inorganic salts do not require addition of extra lime for neutralisation. Inorganic salts such as iron (III) chloride and magnesium chloride can eliminate inhibition of lignin by metal complexation. However, added cost and the possibility of enzyme inhibition by the inorganic salts can prevent the use of such catalyst in the organosolv process. It was reported in ethanol-organosolv pretreatment of Pitch pine carried out in the presence of three separate catalysts such as $1 \% \mathrm{H}_{2} \mathrm{SO}_{4}, 1 \%$ magnesium chloride and $2 \%$ sodium hydroxide resulted in different percent of enzymatic hydrolysis of cellulose such as $55-60 \%, 60 \%$ and $80 \%$ respectively [51].

A combination of biological pretreatment followed by ethanol organosolv, known as bioorganosolv, used to treat Pinus radiata wood chips with white rot Ceriporiopsis subvermispora resulted in a pulp with 89 to $92 \%$ cellulose and low lignin content (6.1 to $8.1 \%)$. This combinatorial pretreatment leads to complete enzymatic hydrolysis of cellulose compared to only $55 \%$ hydrolysis in the case of ethanol organosolv substrate [57]. Pinus radiata chips were incubated with the brown rot fungus Gloeophyllum trabeum for 4 to 12 weeks followed by ethanol-organosolv treatment at $60 \% \mathrm{v} / \mathrm{v}$ ethanol, $200{ }^{\circ} \mathrm{C}$ for
$60 \mathrm{~min}$. Enzymatic hydrolysis of cellulose gave 55-70\% glucose for brown rot + ethanol-organosolv combined pretreatment while without brown rot pretreatment gave cellulose conversion between 30 and $40 \%$. The bioorganosolv process requires a very long incubation time and significant carbohydrate losses when brown-rot fungus such as Gloeophyllum trabeum is used resulted in 9 to $21 \mathrm{wt} \%$ loss of glucan [58].

A hybrid organosolv-steam explosion method efficiently fractionates and reduced size of spruce biomass and yields pretreated solids with high cellulose content $(72 \% \mathrm{w} / \mathrm{w})$, owing to efficient hemicellulose (90.2\%) and lignin (79.4\%) removal at steam explosion and organosolv stages respectively. At the end of the hybrid pretreatment, enzymatic hydrolysis gave almost $61 \%$ glucose yield compared to when only steam explosion was used as a control giving 50\% glucose yield [59].

Oxiorganosolv process is a recent modification to the basic organosolv process using oxygen gas to depolymerise and remove lignin. This method can remove up to $97 \%$ of the lignin using various organic solvents such as acetone, ethanol and tetrahydrofuran. This process generates a minimum amount of sugar degradation products with $100 \%$ cellulose recovery in the pulp and almost $60 \%$ enzymatic cellulose conversion to glucose. This process has potential to explore further, provided safety and cost of the process is regulated [60]. A microwave-assisted ethanol-organosolv pretreatment showed enzymatic hydrolysis of cellulose up to $80 \%$ at $1.5 \%$ substrate consistency; however, scale up of the enzymatic hydrolysis step using higher substrate concentrations of 7.5\% decreased enzymatic hydrolysis of cellulose to almost $60 \%$ [61]. Recently, ultrasonic and microwave (480 W)-assisted ethylene glycol (94 wt\%) organosolv pretreatment performed at $150{ }^{\circ} \mathrm{C}$ on pine wood produced levoglucosan $(55.9 \mathrm{wt} \%)$, hemicellulosic sugars (20 wt \%) and phenols (14 wt \%). This process exhibits no enzymes are required to get value-added products from softwood [52].

Another variation is mild $\left(170{ }^{\circ} \mathrm{C}\right.$ and $\left.60 \mathrm{~min}\right)$ organosolv pulping in the presence of sub-/super-critical $\mathrm{CO}_{2}$, which resulted in increased delignification of industrial softwood sawdust [62]. However, removal of hemicellulose prior to organosolv pretreatment in the presence of sub-/super-critical $\mathrm{CO}_{2}$ has a deleterious effect on delignification. This is opposite to the two-stage combinative organosolv process discussed in the Sect. 3.3, where pre-extraction of hemicelluloses has a positive effect on delignification.

\section{Effect of different organosolv pretreatments on the enzymatic hydrolysis of softwood}

There are two main groups of factors that affect the enzymatic hydrolysis of organosolv cellulose-enzyme-related and substrate-related factors [27]. Additionally, CS factor 
of organosolv process also affects enzymatic hydrolysis of cellulose. These factors are described below with examples from softwood.

\subsection{Effect of enzyme-related factors}

Enzyme-related factors mainly focus on the improvement in the enzyme activity, including improved enzyme adsorption on cellulose, increased enzyme thermal stability, enzyme reusability and synergism with accessory enzymes [24, 63]. The enzymatic digestibility of organosolv Japanese cypress reached to $70 \%$ by changing the enzyme from acremonium cellulase to Accellerase1500. This increase was corroborated to the better binding of Accellerase enzyme to the organosolv-treated substrate [64]. It was observed during enzymatic hydrolysis of organosolv-treated Douglas fir and pine that supplementation of $\beta$-glucosidase improves cellulose hydrolysis by reducing end-product inhibition by cellobiose, while xylanase supplementation increases the accessibility of cellulose to cellulases [65]. Softwood lignin is a major hindrance in enzymatic hydrolysis due to its nonproductive adsorption of enzymes [66, 67]. Ethanol organosolv pretreatment removes lignin and can depolymerise cellulose to form more short fibres and provide more binding sites for the enzymes [19]. Delignification of Norway spruce was increased from 20 to $65 \%$ with increased ethanol organosolv temperature from 175 to $235^{\circ} \mathrm{C}$. A complete enzymatic hydrolysis of cellulose was achieved at $65 \%$ delignification [53]. In addition, the physical redistribution of lignin in a softwood substrate also plays an important role in the improvement of enzymatic hydrolysis of cellulose. Increasing the hydrophilic property of the substrate, such as introducing more acidic or sulphonic functionality on the lignin, can decrease the non-productive adsorption of cellulase on lignin [68].

\subsection{Effect of substrate-related factors}

The substrate-related factors are mainly concerned with the improvement of accessibility of enzymes to cellulose [69]. Del-Rio et al. [41] showed chemical composition of the substrate and substrate-related factors both have a significant effect on the enzymatic hydrolysis of organosolv-treated beetle-killed lodgepole pine. The same group [70] demonstrated that when organosolv-treated lodgepole pine was PFI-mill refined and fibre fractionated in the size range of 0.2 to $3.4 \mathrm{~mm}$, the fibre size has little influence on enzymatic hydrolysis of cellulose. Hemicellulose can shield enzyme access to the cellulose $[67,68]$. As discussed in the twostage combinative organosolv pretreatment in Sect. 3.3, removing hemicellulose at the pre-hydrolysis stage can benefit subsequent organosolv process. Bouxin et al. [71] reported hydrolysis of hemicellulose and conversion of monosaccharides into ethyl glycosides in the acid-catalysed organosolv liquid fraction of Sitka spruce. Almost 12.5 wt $\%$ of ethyl glycoside was produced which is a valuable biorefinery product. In the literature, many substrate factors, such as the contents of hemicellulose and lignin [30, 31, 72], accessible surface area, porosity [41] and swelling of the fibres and crystallinity of cellulose [7, 8], demonstrated to affect the enzymatic hydrolysis of cellulose after organosolv treatment. Ethanol-organosolv treatment on recycled wood (softwood + hardwood) which is a heterogeneous and dry material compared to the typical softwood used in the biorefinery leads to incomplete or severe organosolv treatment on the recycled wood. This reduced enzymatic hydrolysis of recycled wood compared to the typical softwood such as spruce [73]. It was noted that pulp drying after organosolv treatment also affects enzymatic hydrolysis of cellulose [44]. The effects of different ethanol organosolv pretreatments on the characteristics of substrate-related factors are shown in Table 2.

The results on $\%$ cellulose conversion by enzymatic hydrolysis of organosolv-pretreated softwood are compiled in Table 3. It is to be noted that enzyme loading and the amount of pretreated softwood biomass used in the enzymatic hydrolysis varied in the literature, thereby making direct comparison between different studies difficult.

\subsection{Effect of pretreatment severity and temperature}

In Fig. 2, the percent enzymatic hydrolysis of softwood cellulose data is plotted against severity factor $\left(S_{0}\right)$ and pretreatment temperature as applied in different ethanol organosolv pretreatments in the literature. The $\mathrm{pH}$ of organosolv
Table 2 Effect of different ethanol organosolv pretreatments on the characteristics of (softwood) substrate-related factors

\begin{tabular}{llllll}
\hline Pretreatment & $\begin{array}{l}\text { Hemicellulose } \\
\text { removal }\end{array}$ & $\begin{array}{l}\text { Lignin } \\
\text { removal }\end{array}$ & Accessible area & $\begin{array}{l}\text { Cellulose de- } \\
\text { crystallisation }\end{array}$ & Toxic inhibitors \\
\hline Basic & $\mathrm{H}$ & $\mathrm{M}$ & $\mathrm{H}$ & $\mathrm{H}$ & $\mathrm{M}$ \\
Acid & $\mathrm{H}$ & $\mathrm{M}$ & $\mathrm{H}$ & $\mathrm{ND}$ & $\mathrm{H}$ \\
Alkaline & $\mathrm{L}$ & $\mathrm{H}$ & $\mathrm{H}$ & $\mathrm{ND}$ & $\mathrm{L}$ \\
Other $\left(\right.$ e.g. $\left.\mathrm{FeCl}_{3}\right)$ & $\mathrm{H}$ & $\mathrm{M}$ & $\mathrm{ND}$ & $\mathrm{ND}$ & $\mathrm{ND}$ \\
\hline
\end{tabular}

$H$ high effect, $L$ low effect, $M$ medium effect, $N D$ not determined 
Table 3 Effect of different organosolv pretreatments on enzymatic hydrolysis of softwood cellulose

\begin{tabular}{|c|c|c|c|c|c|c|c|}
\hline Pretreatment & Softwood & wt $\%$ ethanol & Catalyst & Temp $\left({ }^{\circ} \mathrm{C}\right)$ & Time (min) & $\begin{array}{l}\text { Cellulose } \\
\text { hydrolysis }\end{array}$ & Reference \\
\hline \multirow[t]{4}{*}{ Ethanol } & Recycled wood & 35 & No & 220 & 180 & $71.4 \%$ in $48 \mathrm{~h}$ & Lesar et al. [73] \\
\hline & $\begin{array}{l}\text { Pinus psudos- } \\
\text { trobus }\end{array}$ & 60 & No & 80 & 90 & $20 \%$ in $72 \mathrm{~h}$ & $\begin{array}{l}\text { Farías-Sánchez } \\
\text { et al. [96] }\end{array}$ \\
\hline & $\begin{array}{l}\text { Jack pine (Pinus } \\
\text { bank siana) }\end{array}$ & 50 & No & 190 & 240 & $24 \%$ in $72 \mathrm{~h}$ & Xu et al. [13] \\
\hline & Pinus radiata & 60 & No & 200 & 60 & $100 \%$ in $72 \mathrm{~h}$ & Muñoz et al. [57] \\
\hline \multirow[t]{17}{*}{ Acid } & \multirow[t]{2}{*}{$\begin{array}{l}\text { Loblolly pine } \\
\quad(\text { Pinus taeda) }\end{array}$} & 65 & $1.1 \% \mathrm{H}_{2} \mathrm{SO}_{4}$ & 170 & 60 & $70 \%$ in $80 \mathrm{~h}$ & $\begin{array}{l}\text { Sannigrahi, Miller } \\
\text { et al. [8] }\end{array}$ \\
\hline & & 65 & $1.1 \% \mathrm{H}_{2} \mathrm{SO}_{4}$ & 170 & 60 & $76.4 \%$ & Li et al. [30] \\
\hline & \multirow{5}{*}{$\begin{array}{l}\text { Lodgepole pine } \\
\text { (Pinus con- } \\
\text { torta) }\end{array}$} & 65 & $1.1 \% \mathrm{H}_{2} \mathrm{SO}_{4} / \mathrm{SO}_{2}$ & 170 & 60 & $100 \% / 71 \%$ & Del Rio et al. [41] \\
\hline & & 48 to 82 v\% & $\begin{array}{c}0.76-1.44 \% \\
\mathrm{H}_{2} \mathrm{SO}_{4}\end{array}$ & $153-187$ & $43-77$ & $97 \%$ & $\begin{array}{l}\text { Pan et al. [2]; Pan } \\
\text { et al. [19] }\end{array}$ \\
\hline & & 60 & $1 \% \mathrm{H}_{2} \mathrm{SO}_{4}$ & 170 & 50 & $53.1 \%$ after $72 \mathrm{~h}$ & $\begin{array}{l}\text { Nakagame et al. } \\
\text { [31] }\end{array}$ \\
\hline & & 75 & $1 \% \mathrm{H}_{2} \mathrm{SO}_{4}$ & 180 & 45 & $100 \%$ after $72 \mathrm{~h}$ & Chandra et al. [69] \\
\hline & & 50 & $10 \%(\mathrm{v} / \mathrm{v}) \mathrm{H}_{2} \mathrm{SO}_{4}$ & 195 & 60 & $23 \%$ in $12 \mathrm{~h}$ & Berlin et al. [65] \\
\hline & Pinus radiata & $60 \mathrm{v} \%$ & $\begin{array}{l}0.13 \% \mathrm{H}_{2} \mathrm{SO}_{4} \\
(\mathrm{w} / \mathrm{v})\end{array}$ & 185 & 18 & ND & Monrroy et al. [97] \\
\hline & \multirow[t]{2}{*}{ Norway spruce } & $63 \%$ & $\begin{array}{l}\text { Formic acid } \\
\qquad(0.05 \mathrm{~mol} / \mathrm{L}) \\
\text { pH } 3.5\end{array}$ & 230 & 120 & $100 \%$ in $48 \mathrm{~h}$ & $\begin{array}{l}\text { Agnihotri et al. } \\
\text { [53] }\end{array}$ \\
\hline & & $60 \%$ & $1.0 \% \mathrm{H}_{2} \mathrm{SO}_{4}$ & 182 & 60 & $69.1 \%$ in $48 \mathrm{~h}$ & $\begin{array}{l}\text { Matsakas et al. } \\
\text { [98] }\end{array}$ \\
\hline & Sitka spruce & $50-70$ v\% & $0.75-1.25 \%$ & $150-180$ & $25-85$ & $86 \%^{\mathrm{a}}$ & Bouxin et al. [71] \\
\hline & Japanese cypress & $50 \%$ & $0.4 \% \mathrm{HCl}$ & 170 & 45 & $70 \%$ & Hideno et al. [64] \\
\hline & \multirow[t]{3}{*}{ Douglas fir } & $50 \%$ & pH 2.4 & 188 & 15 & $>90 \%$ in $24 \mathrm{~h}$ & Mabee et al. [99] \\
\hline & & $50 \%$ & $\begin{array}{c}10 \%(\mathrm{~V} / \mathrm{V}) \\
\mathrm{H}_{2} \mathrm{SO}_{4}\end{array}$ & 195 & 40 & $45 \%$ in $12 \mathrm{~h}$ & Berlin et al. [65] \\
\hline & & $50 \%$ & $51 \mathrm{mM} \mathrm{H}_{2} \mathrm{SO}_{4}$ & 195 & 40 & $91 \%$ in $72 \mathrm{~h}$ & Kurabi et al. [100] \\
\hline & $\begin{array}{l}\text { British Colum- } \\
\text { bian hybrid } \\
\text { spruce }\end{array}$ & $50 \%$ & $1.2 \% \mathrm{H}_{2} \mathrm{SO}_{4}$ & 185 & 36 & $>90 \%$ in $72 \mathrm{~h}$ & Berlin et al. [65] \\
\hline & Pine unknown & $75 \%$ & $1.0 \% \mathrm{H}_{2} \mathrm{SO}_{4}$ & 180 & 60 & $17.3 \%$ in $72 \mathrm{~h}$ & $\begin{array}{l}\text { Amiri and Karimi } \\
\text { [7] }\end{array}$ \\
\hline \multirow[t]{3}{*}{ Alkaline } & Norway spruce & $100 \%$ glycerol & $10 \% \mathrm{KOH}$ & 230 & 90 & $87 \%$ & Hundt et al. [44] \\
\hline & Pinus sp. & $45 \% \mathrm{v} / \mathrm{v}$ & $3 \% \mathrm{w} / \mathrm{v} \mathrm{NaOH}$ & 165 & 120 & $95 \%$ in $72 \mathrm{~h}$ & $\begin{array}{l}\text { Bernal-Lugo et al. } \\
\text { [55] }\end{array}$ \\
\hline & Pine wood & $50 \%$ & $\begin{array}{l}0.1 \mathrm{M} \mathrm{FeCl}_{3} ; \mathrm{pH} \\
\quad 1.43\end{array}$ & 170 & 60 & $90 \%$ & Kim et al. [101] \\
\hline \multirow[t]{6}{*}{ Other } & \multirow{2}{*}{$\begin{array}{l}\text { Pine wood } \\
\text { lodgepole } \\
\text { pine (Pinus } \\
\text { contorta) }\end{array}$} & $\begin{array}{l}\text { 95\% Ethylene } \\
\text { glycol }\end{array}$ & $1 \% \mathrm{H}_{2} \mathrm{SO}_{4}$ & 150 & $\mathrm{~b}$ & $\mathrm{c}$ & Yang et al. [102] \\
\hline & & $65 \%$ Butanol & $\begin{array}{l}1.1 \% \mathrm{H}_{2} \mathrm{SO}_{4} / 20 \% \\
\mathrm{NaOH}\end{array}$ & 170 & 60 & $90 \% / 85 \%$ & Del Rio et al. [41] \\
\hline & Douglas Fir & $95 \%$ acetic acid & No & 110 & 300 & $10 \%$ & Pan et al. [54] \\
\hline & Pinus radiata & $50 \mathrm{v} \%$ acetone & $0.9 \% \mathrm{H}_{2} \mathrm{SO}_{4}$ & 195 & 40 & $72 \%$ in $72 \mathrm{~h}$ & Araque et al. [28] \\
\hline & \multirow[t]{2}{*}{$\begin{array}{l}\text { Pinus radiata } \\
\text { Mixed softwood }\end{array}$} & $\begin{array}{l}\text { Fungal followed } \\
\text { by } 60 \% \text { ethanol } \\
\text { organosolv }\end{array}$ & No & 200 & 60 & $70 \%$ in $24 \mathrm{~h}$ & Fissore et al. [58] \\
\hline & & $\begin{array}{l}\text { 60\% Microwave } \\
\text { followed by } \\
\text { organosolv }\end{array}$ & $0.25 \% \mathrm{H}_{2} \mathrm{SO}_{4}$ & 175 & 60 & $80 \%$ in 12 days & $\begin{array}{l}\text { Abdou Alio } \\
\text { et al. }[52,61]\end{array}$ \\
\hline
\end{tabular}


Table 3 (continued)

\begin{tabular}{|c|c|c|c|c|c|c|c|}
\hline Pretreatment & Softwood & wt $\%$ ethanol & Catalyst & Temp $\left({ }^{\circ} \mathrm{C}\right)$ & Time (min) & $\begin{array}{l}\text { Cellulose } \\
\text { hydrolysis }\end{array}$ & Reference \\
\hline & Pinus radiata & $\begin{array}{l}\text { Autohydrolysis } \\
\text { (AH) followed } \\
\text { by } 50 \% \text { orga- } \\
\text { nosolv }\end{array}$ & $1 \% \mathrm{H}_{2} \mathrm{SO}_{4}$ & $\begin{array}{l}\text { AH at } 150, \\
\text { organosolv } \\
\text { at } 185\end{array}$ & $\begin{array}{l}\text { AH } 30 \text { min, } \\
\text { organosolv } \\
75 \text { min }\end{array}$ & $63 \%$ in $96 \mathrm{~h}$ & Santos et al. [4] \\
\hline & Norway Spruce & $\begin{array}{l}52 \% \text { organosolv } \\
\text { followed by } \\
\text { steam explo- } \\
\text { sion }\end{array}$ & $1 \% \mathrm{H}_{2} \mathrm{SO}_{4}$ & 200 & 30 & $61 \%$ in $48 \mathrm{~h}$ & $\begin{array}{l}\text { Matsakas et al. } \\
\text { [59] }\end{array}$ \\
\hline
\end{tabular}

\footnotetext{
${ }^{\mathrm{a}}$ Hemicellulose to ethyl glucosides under optimal conditions

${ }^{\mathrm{b}}$ Ten-minute heating with ultrasonication followed by 10 min heating with microwave radiation

${ }^{c}$ Yields of levoglucosan $=56 \%$, hemicellulose sugars $=20 \%$ and phenol $=14 \%$, respectively
}

process in the presence of catalyst is not often reported in the literature and those reported are the starting $\mathrm{pH}$, which gradually changes over the course of the organosolv reaction. Therefore, $S_{0}$ values in Fig. 2 are calculated from Eq. 1. This helps in comparison of different organosolv processes as shown in the Fig. 2. The most effective range of $S_{0}$ factor in the percent enzymatic hydrolysis of organosolv-treated softwood cellulose is between 3.5 and 4.8 , which correlates with a pretreatment temperature of 165 to $205^{\circ} \mathrm{C}$. This pretreatment severity applied for softwood is higher compared to other lignocellulosic biomass such as hardwood, grasses and energy crops due to the recalcitrant nature of the softwood. It can be seen from Fig. 2 that process temperature can be a good indicator in understanding how pretreatment severity affects enzymatic hydrolysis of organosolv softwood cellulose.

The acid-ethanol organosolv pretreatment gave consistently higher enzymatic hydrolysis yield, almost $100 \%$ conversion for Pinus contorta [41, 69] and Norway spruce [53], compared to ethanol organosolv which reported only one $100 \%$ conversion for Pinus radiata [57] whereas alkaline and other organosolv processes gave a maximum of $95 \%$ [55] and 90\% [41] cellulose conversion yields respectively. Generally, a spread of enzymatic cellulose conversion from less than $20 \%$ to almost $100 \%$ can be seen. From Fig. 2, the enzymatic conversion depends on the type of softwood, type of catalyst used and other process parameters.

\section{Physico-chemical changes and applications of softwood fractionated components after organosolv pretreatment}

The general physico-chemical changes associated with basic ethanol organosolv process are (1) hydrolysis of glycosidic bonds in hemicellulose and cellulose; (2) hydrolysis of the internal bonds in lignin as well as lignin-hemicellulose bonds, particularly ether and 4-O-methylglucuronic acid ester bonds to the $\alpha$-carbons of the lignin units, giving smaller lignin fragments; (3) acid-catalysed degradation of pentose into $\mathrm{F}$ and hexose into HMF, of which both are enzyme and fermentation inhibitors; (4) condensation reactions between lignin fragments and the reactive aldehydes generated by the sugar degradation products which will produce pseudo-lignins; and (5) modification of the side-chain functional group, for example $-\mathrm{OH}$ by ethoxylation. The different degrees of physicochemical changes in the softwood due to organosolv pretreatment mainly depend on the CS of the pretreatment [24]. The physico-chemical changes and post-organosolv treatment application of individual softwood components are discussed below:

\subsection{Cellulose}

Under optimum pretreatment conditions, depolymerisation of the less-ordered (amorphous) fraction of cellulose leads to short cellulose fibres which could provide more binding sites and increased accessibility to the enzymes [19]. In the case of Loblolly pine, an increase in cellulose $I_{\beta}$ and decrease in cellulose $I_{\alpha+\beta}$ and para-crystalline forms for organosolvtreated cellulose was reported. However, after enzymatic hydrolysis, the relative proportion of cellulose $I_{\beta}$ and cellulose $I_{\alpha+\beta}$ was increased by almost three times with accompanied decrease in the para-crystalline form of cellulose [8]. The less-ordered amorphous cellulose is an ideal substrate for the enzymatic hydrolysis since cellulose hydrolysis mediated by fungal cellulase enzymes is typically 3 to 30 times faster for amorphous and para-crystalline forms of cellulose compared to long-range ordered crystalline cellulose $[8,74]$. Hence, the aim of any organosolv process is to increase the amorphous:crystalline ratio of cellulose.

The cellulose-rich pulp is mainly used in enzymatic hydrolysis to produce glucose, which can then be 
Fig. 2 Effect of organosolv pretreatment on enzymatic hydrolysis of different softwood substrates
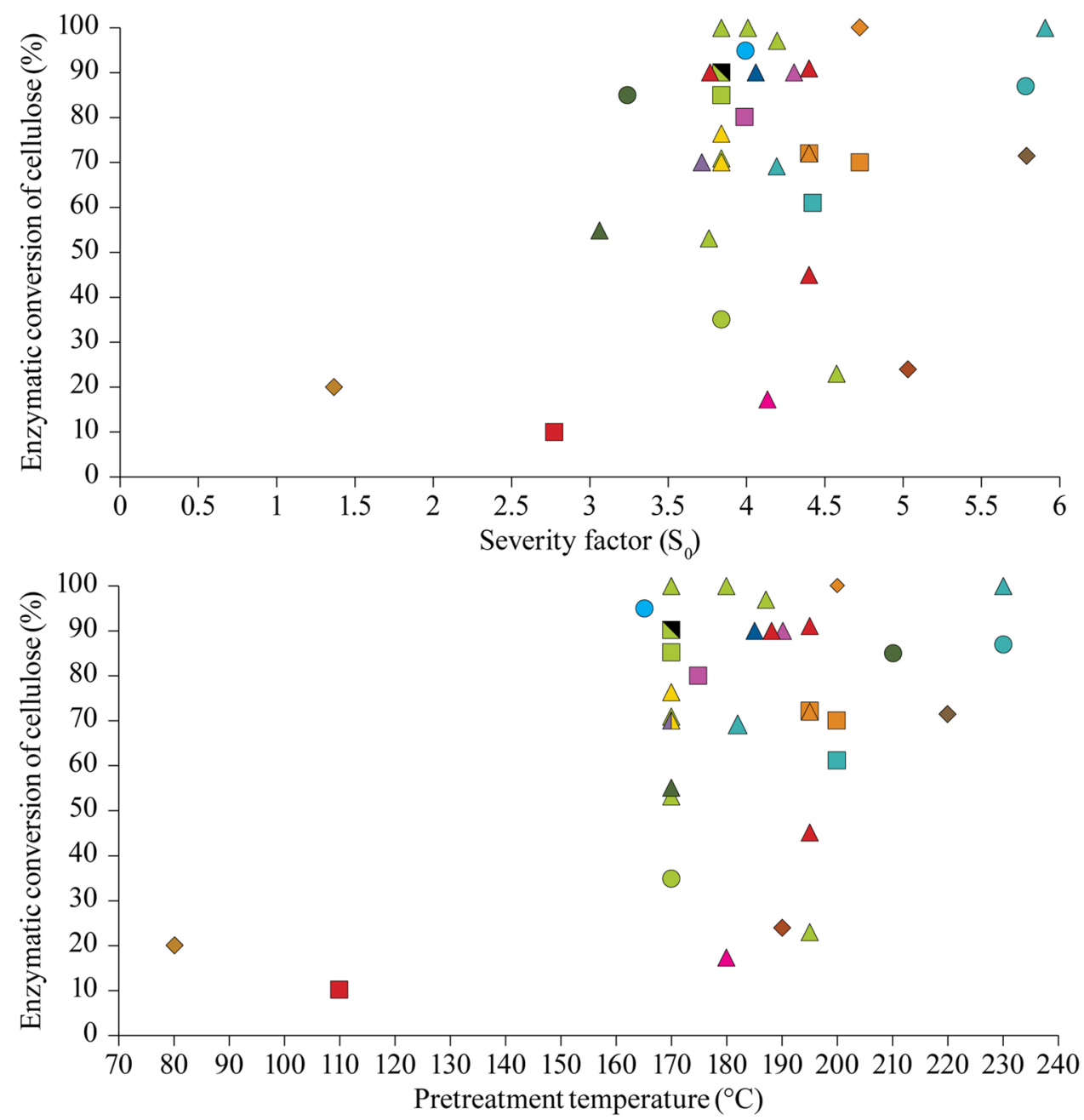

Acid $\Delta \Delta \Delta \Delta \Delta \Delta \Delta \Delta \Delta \Delta \Delta \Delta \Delta \Delta \Delta$

Alkaline $\bigcirc \circ \quad 0 \quad 0 \quad 0 \quad 0 \quad 0 \quad 0 \quad 0 \quad 0 \quad 0 \quad 0 \quad 0 \quad 0 \quad$

Other

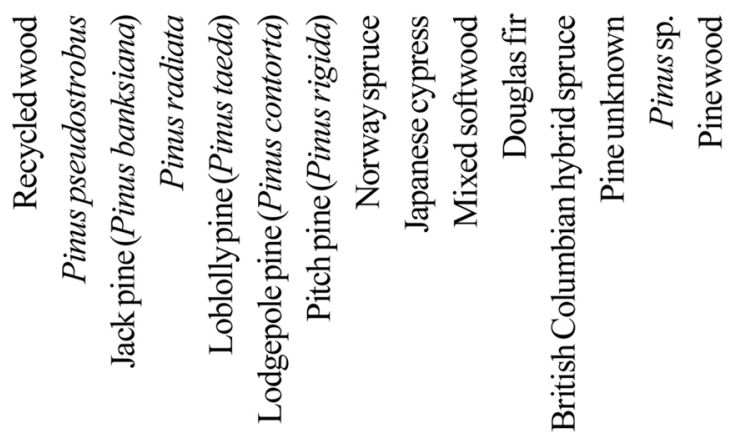

fermented to ethanol, acetone-butanol-ethanol (ABE) [7], biohydrogen, single cell oil, succinic acid and lactic acid. The other uses of cellulose-rich pulp are in the production of dissolving pulp, microcrystalline cellulose, carboxymethyl(ethyl)cellulose and nano-fibrillated cellulose $[10,27,75]$.

\subsection{Lignin}

Delignification to reduce overall lignin content is a major attribute of the ethanol organosolv process. Lignin molecular weight and polydispersity index are influenced by pretreatment conditions. The fragmentation of lignin is mainly 
ascribed to the cleavage of ether linkages which are 40 to $65 \%$ of the total linkages in the softwood lignin. In acidicethanol organosolv process, easily hydrolysable $\alpha$-ether linkages are most readily broken [68]. New phenolic $-\mathrm{OH}$ groups are produced by cleavage of the $\beta$-aryl ether linkage. However, the rate and reaction pathway of $\beta-\mathrm{O}-4$ cleavage is dependent on the mineral acids used for catalysis as well as the combined pretreatment severity [76]. During the acid-catalysed process, pseudo-lignins may be formed by the copolymerisation of lignin- and carbohydrate-degraded products. This substance usually contains large amounts of unsaturated carbon with polyphenolic structure, and adheres to the surface of cellulose pulp, which is detrimental to further delignification and enzymatic hydrolysis of the organosolv substrates [22, 77]. Generally, at the end of ethanol organosolv or organic acid-ethanol organosolv pretreatments, the total lignin content and aliphatic $-\mathrm{OH}$ functionality decreases. The amount of phenolic condensed lignin, phenolic $-\mathrm{OH}$ and carboxylic functionality increases compared to the original lignocellulosic biomass [78]. The carboxyl and sulfonyl groups introduced on the residual lignin in acid-catalysed ethanol organosolv-treated softwood substrate results in an increase in the anionic charge (therefore hydrophilicity) of the lignin present in the pulp that ultimately improves the enzymatic hydrolysis of cellulose [79]. Lai et al. [80] demonstrated correlation between the distribution of cellulase enzymes on organosolv lignin and the changes in cellulose hydrolysis yields. Further, Huang et al. [81] showed inhibitory or stimulatory effects of organosolv lignin as a function of both hydrophobic interactions and electrostatic repulsions with cellulase enzymes.

Majority of the lignin-rich fraction is used in energy production and an additional small fraction has potential in value-added products such as manufacturing of resins [82, 83], dispersants, binding agents [84], coating, plasticiser filler [85], stabilising agents [86], carbon fibres and nanoparticles [86]. In renewable bioenergy, the lignin-rich fraction can be used in the production of bio-oil, aromatics and syngas [87].

\subsection{Hemicellulose}

With increased concentration of acid in the ethanol organosolv process, hemicelluloses are hydrolysed easily to form oligomeric and monomeric sugars; however, as pretreatment severity increases further, enzyme and fermentation inhibitors such as F, HMF, levulinic acid and formic acid are formed. Acetic acid released is not a sugar degradation product but the product of the hydrolysis of the acetyl groups of hemicellulose [88]. The hemicellulose-rich stream can be used in the production of ethanol, methane, barrier films, hydrogels [89], prebiotics [90] and rhamnolipids.

\section{Pilot and demonstration scale organosolv processes and challenges for commercialisation}

Some organosolv processes studied or being developed towards pilot and demonstration scale include the alcoholbased Alcell ${ }^{\mathrm{TM}}$ (Lignol Innovations, Canada) and ECN (Netherlands), Organocell (Germany), American Science and Technology (AST) (USA), organic acid-based CIMV (France) and Chempolis (Finland), and glycerol-based Glycell $^{\mathrm{TM}}$ (Leaf Resources, Australia) process [23]. However, the following organosolv processes were promising but did not progress to commercialisation owing to challenges including high process cost (e.g. solvent), energy consumption (e.g. solvent recovery) and subject to the fluctuation of fossil oil prices.

\subsection{The Lignol process}

This process was proposed for a biorefinery based on ethanol organosolv pulping of mixed softwoods. The cellulose fraction of the pulp was converted to glucose using enzymatic hydrolysis followed by subsequent fermentation to produce ethanol [32]. The lignin extracted is a suitable feedstock for production of lignin-based adhesives and other products due to its high purity, low molecular weight and abundance of reactive groups. Additional coproducts were derived from the hemicellulose sugars and furfural recovered from the water-soluble stream. Another advantage of the Lignol process is that the process has good economic fundamentals provided efficient engineering design is co-developed for the recovery of solvent and valuable co-products. Otherwise, high energy consumption for solvent recovery is a limitation of this process.

Based on the Lignol process, the first end-to-end production of cellulosic ethanol from woodchips at fully integrated industrial scale biorefinery plant in Burnaby, British Columbia, was completed in 2009. Generally, wood biomass is treated under a cooking temperature of 180 to $195{ }^{\circ} \mathrm{C}$ for 30 to 90 min with an ethanol concentration of $35 \mathrm{wt}$ to $70 \mathrm{wt} \%$ at a liquor to solids weight ratio from $4: 1$ to $10: 1$. The $\mathrm{pH}$ of the liquor might range from 2.0 to 3.8 . The cellulose-rich pulp generates a high yield of glucose after enzymatic hydrolysis. The glucose is readily converted to ethanol or other sugar platform chemicals using appropriate fermentation technologies. The liquor after the organosolv step is processed to recover lignin, furfural, xylose and other extractives [91]. Lignol was acquired by Canadian Fibria Celulose SA and changed its name to Fibria Innovations Inc. which was running until the year 2018. It has now merged with Suzano pulp and paper, Brazil. 


\subsection{LignoFibre process}

The LignoFibre process was developed at VTT, Finland. This process is based on cooking with organic solvents, such as acetic acid or ethanol, at elevated temperatures (130 to $150{ }^{\circ} \mathrm{C}$ ) for 3 to $4 \mathrm{~h}$. In this process, phosphinic acid $\left(\mathrm{H}_{3} \mathrm{PO}_{2}\right)$, an expensive catalyst, is used as a reducing agent in delignification by acidolysis. $\mathrm{H}_{3} \mathrm{PO}_{2}$ also potentially protects lignin against typical condensation reactions via esterification under acidic conditions. However, at higher cooking temperature $\left(>150{ }^{\circ} \mathrm{C}\right)$ and longer time (5 $\mathrm{h}$ and above), degradation and condensation of dissolved carbohydrates and lignin with formation of pseudolignin is observed. LignoFibre process is found to be flexible towards various feedstocks such as hardwood and softwood, as well as various annual plants. This process yields high quality components, i.e. reactive and/or easily hydrolysed cellulose fibres, sulphur-free lignin and sugar compounds, which can be potentially used as bio-based materials in various applications [92]. Additional information on commercial use of this process is not available.

\subsection{Alcell process}

The Alcell process was originally called alcohol and pulping process [93]. It has three stages of extraction and uses an aqueous ethanol solution ( 40 to $60 \% \mathrm{v} / \mathrm{v}$ ) to delignify wood in the temperature range 180 to $210{ }^{\circ} \mathrm{C}$ with pressure ranging from 2 to $3.5 \mathrm{MPa}$. The solvent was recovered by flash vaporisation, vapour condensation and vacuum stripping. In August 1983, a pilot plant for the Alcell process was started. This plant operation showed that the production costs were lower than those of Kraft or sulphite pulp [94]. Both lignin and hemicellulose sugars could be recovered in high yields as attractive by-products. The first demonstration scale plant using the Alcell process operated from 1989 to 1996 in New Brunswick, Canada. In 1993, more than 2,000 cooks were completed in the Alcell demonstration plant. Alcell process is economically viable at a smaller scale compared to the Kraft process to produce chemical pulp and has been considered an alternative to Kraft pulping [95]. The small scale makes it an attractive process especially for some limited wood resources.

In the Alcell process, there are no recovery boilers because no inorganic materials need to be recycled. The absence of recovery boilers means that the Alcell process can achieve a big saving in the capital cost. In addition, lignin free of sodium and sulphur but having more condensed phenolic units recovered from the solvent liquor can be used to produce value-added products. The condensation reactions are responsible for the deceleration of the delignification of softwoods. The residual condensed lignin in the pulp reduces enzymatic hydrolysis of cellulose. Alcell Inc. has been discontinued and there are no further plants running on this process; the reasons are unknown.

\section{Future perspectives}

Organosolv fractionation of softwood has been established at pilot and demonstration scale; however, developing commercial scale is hindered mainly by unfavourable process and energy cost and fluctuating prices of fractionated product streams. Therefore, overall cost reduction and energy balance of the organosolv process must be addressed with efficient separation of pure fractionated components. The organosolv pretreatment cost and energy requirement can be reduced by operating at low temperature and/or atmospheric pressures. This can be achieved by developing novel catalysts and/or combinatorial pretreatment processes using high-boiling-point organic solvents which are successfully demonstrated at the Laboratory scale discussed in Sect. 3.3. For the expected combinatorial organosolv pretreatment to have commercial success, it may be required to apply a presoaking or pre-extraction step in which hemicellulose sugars are extracted from the biomass and the remaining biomass used for the organosolv pretreatment for delignification. This two-stage combined pretreatment approach can result in a clean separation of cellulose, lignin and hemicellulose from softwood [51, 56]. The resulting cellulose pulp can be enzymatically hydrolysed to sugars under mild and environment friendly operating conditions. However, fine tuning of the organosolv process is essential either from a viewpoint of different types of softwood used as a feedstock or focus on producing cellulose pulp with enhanced enzymatic hydrolysis. Further, investigation into the amount of residual lignin left in the cellulosic pulp, generation of degradation products/inhibitors or pure lignin recovery yields are vital components for a commercial organosolv process to be successful and viable.

\section{Conclusions}

Softwood biomass represents a significant lignocellulosic feedstock; however, its potential in the biorefinery has not been fulfilled due to its natural recalcitrance. There are different pretreatments developed for softwood to improve its value as a feedstock in biofuel and in the biorefinery industry. Ethanol-based organosolv pretreatment is an effective pretreatment to improve the enzymatic digestibility of softwood. Addition of catalysts such as acid or alkali could assist ethanol organosolv pretreatment to be performed at mild conditions. The organosolv process keeps most of the cellulose fraction in the pulp by selectively removing lignin and hemicellulose. The isolated lignin is of high purity with 
low sugar and inorganic ash content and with reactive functional groups that allow its use in a variety of applications. It is anticipated that lower amounts of residual lignin left in the pulp can reduce non-productive adsorption of enzymes and thereby allow expensive enzymes to be recycled and reused, influencing the cost of the softwood pretreatment process. Moreover, lower amounts of residual lignin and higher proportion of amorphous cellulose in the organosolv softwood pulp can result in the improved enzymatic hydrolysis to glucose; the latter can be fermented to various value-added platform biochemicals, biofuels and biopolymers.

Acknowledgements The authors would like to acknowledge Kim McGrouther and Garth Weinberg for providing critical comments on this review and Dale Corbett and Milla Baker for graphics and bibliography support respectively.

Author contribution Alankar A Vaidya: conceptualisation, visualisation, investigation, writing - original draft preparation, reviewing, editing, revising original draft. Karl Murton: conceptualisation, visualisation, funding, writing-reviewing, editing. Dawn A Smith: conceptualisation, visualisation, writing-reviewing, editing. Gaetano Dedual: conceptualisation, visualisation, writing—reviewing, editing.

Funding Open Access funding enabled and organized by CAUL and its Member Institutions. This work was supported by the New Zealand Government's Ministry of Business, Innovation and Employment via Scion's Strategic Science Investment Fund and Pre-Seeding Accelerator Fund.

\section{Declarations}

Competing interests The authors declare no competing interests.

Open Access This article is licensed under a Creative Commons Attribution 4.0 International License, which permits use, sharing, adaptation, distribution and reproduction in any medium or format, as long as you give appropriate credit to the original author(s) and the source, provide a link to the Creative Commons licence, and indicate if changes were made. The images or other third party material in this article are included in the article's Creative Commons licence, unless indicated otherwise in a credit line to the material. If material is not included in the article's Creative Commons licence and your intended use is not permitted by statutory regulation or exceeds the permitted use, you will need to obtain permission directly from the copyright holder. To view a copy of this licence, visit http://creativecommons.org/licenses/by/4.0/.

\section{References}

1. Kim H, Choi B (2010) The effect of biodiesel and bioethanol blended diesel fuel on nanoparticles and exhaust emissions from CRDI diesel engine. Renew Energy 35(1):157-163. https://doi. org/10.1016/j.renene.2009.04.008

2. Pan X, Xie D, Yu RW, Lam D, Saddler JN (2007) Pretreatment of Lodgepole pine killed by mountain pine beetle using the ethanol organosolv process: fractionation and process optimization. Ind Eng Chem Res 46(8):2609-2617. https://doi.org/10.1021/ie061 5761
3. Puri M, Abraham RE, Barrow CJ (2012) Biofuel production: prospects, challenges and feedstock in Australia. Renew Sustain Energy Rev 16(8):6022-6031. https://doi.org/10.1016/j.rser. 2012.06.025

4. Santos TM, Rigual V, Oliet M, Alonso MV, Domínguez JC, Rodriguez F (2019) Two-step fractionation of Pinus radiata by autohydrolysis and organosolv delignification for enzymatic hydrolysis. J Chem Technol Biotechnol 94(12):3951-3959. https://doi. org/10.1002/jctb.6197

5. Forest Owners Association (2020) Facts and figures. https:// www.nzfoa.org.nz/resources/publications/facts-and-figures. Accessed 17 May 2021.

6. Fahmy M, Sohel MI, Vaidya AA, Jack MW, Suckling ID (2019) Does sugar yield drive lignocellulosic sugar cost? Case study for enzymatic hydrolysis of softwood with added polyethylene glycol. Process Biochem 80:103-111. https://doi.org/10.1016/j. procbio.2019.02.004

7. Amiri H, Karimi K (2015) Improvement of acetone, butanol, and ethanol production from woody biomass using organosolv pretreatment. Bioprocess Biosyst Eng 38(10):1959-1972. https:// doi.org/10.1007/s00449-015-1437-0

8. Sannigrahi P, Miller SJ, Ragauskas AJ (2010) Effects of organosolv pretreatment and enzymatic hydrolysis on cellulose structure and crystallinity in Loblolly pine. Carbohydr Res 345(7):965970. https://doi.org/10.1016/j.carres.2010.02.010

9. Sannigrahi P, Ragauskas AJ, Miller SJ (2010) Lignin structural modifications resulting from ethanol organosolv treatment of Loblolly Pine. Energy Fuels 24(1):683-689. https://doi.org/10. 1021/ef900845t

10. Kandhola G, Djioleu A, Carrier DJ, Kim J-W (2017) Pretreatments for enhanced enzymatic hydrolysis of pinewood: a review. BioEnergy Res 10(4):1138-1154. https://doi.org/10.1007/ s12155-017-9862-3

11. Nitsos C, Rova U, Christakopoulos P (2018) Organosolv fractionation of softwood biomass for biofuel and biorefinery applications. Energies 11(1):50. https://doi.org/10.3390/en11010050

12. Wijeyekoon SLJ, Vaidya AA (2021) Woody biomass as a potential feedstock for fermentative gaseous biofuel production. World J Microbiol Biotechnol 37(8):134. https://doi.org/10.1007/ s11274-021-03102-6

13. Xu C, Liao B, Shi W (2013) Organosolv pretreatment of pine sawdust for bio-ethanol production. In: Fang Z (ed) Pretreatment techniques for biofuels and biorefineries. Springer, Berlin, Heidelberg, pp 435-457

14. Alvira P, Tomás-Pejó E, Ballesteros M, Negro MJ (2010) Pretreatment technologies for an efficient bioethanol production process based on enzymatic hydrolysis: a review. Bioresour Technol 101(13):4851-4861. https://doi.org/10.1016/j.biortech.2009.11. 093

15. Suckling ID, Jack MW, Lloyd JA, Murton KD, Newman RH, Stuthridge TR, Torr KM, Vaidya AA (2017) A mild thermomechanical process for the enzymatic conversion of radiata pine into fermentable sugars and lignin. Biotechnol Biofuels 10(61):1-13. https://doi.org/10.1186/s13068-017-0748-6

16. Paszner L, Behera NC (1985) Beating behaviour and sheet strength development of coniferous organosolv fibers. Holzforschung 39(1):51-61. https://doi.org/10.1515/hfsg.1985.39.1. 51

17. Overend RP, Chornet E, Gascoigne J.A. (1987) Fractionation of lignocellulosics by steam-aqueous pretreatments. Phil Trans R Soc Lond Ser A, Math Phys Sci 321: 523-536. https://www.jstor. org/stable/37798. Accessed 24 Dec 2021

18. Kleinert T, Tayenthal K (1931) Über neuere versuche zur trennung von cellulose und inkrusten verschiedener hölzer. Angew Chem 44:788-791. https://doi.org/10.1002/ange.19310443903 
19. Pan X, Xie D, Yu RW, Saddler JN (2008) The bioconversion of mountain pine beetle-killed lodgepole pine to fuel ethanol using the organosolv process. Biotechnol Bioeng 101(1):39-48. https:// doi.org/10.1002/bit.21883

20. Joseph P, Opedal MT, Moe ST (2021) The O-factor: using the H-factor concept to predict the outcome of organosolv pretreatment. Biomass Conv Bioref. https://doi.org/10.1007/ s13399-021-01667-8

21. Ferreira JA, Taherzadeh MJ (2020) Improving the economy of lignocellulose-based biorefineries with organosolv pretreatment. Bioresour Technol 299:122695. https://doi.org/10.1016/j.biort ech.2019.122695

22. Li M-F, Yang S, Sun R-C (2016) Recent advances in alcohol and organic acid fractionation of lignocellulosic biomass. Bioresour Technol 200:971-980. https://doi.org/10.1016/j.biortech.2015. 10.004

23. Zhang Z, Harrison MD, Rackemann DW, Doherty WOS, O'Hara IM (2016) Organosolv pretreatment of plant biomass for enhanced enzymatic saccharification. Green Chem 18(2):360-381. https://doi.org/10.1039/C5GC02034D

24. Zhao X, Cheng K, Liu D (2009) Organosolv pretreatment of lignocellulosic biomass for enzymatic hydrolysis. Appl Microbiol Biotechnol 82(5):815-827. https://doi.org/10.1007/ s00253-009-1883-1

25. Zhao X, Li S, Wu R, Liu D (2017) Organosolv fractionating pre-treatment of lignocellulosic biomass for efficient enzymatic saccharification: chemistry, kinetics, and substrate structures. Biofuel Bioprod Biorefin 11(3):567-590. https://doi.org/10. 1002/bbb. 1768

26. Haghighi Mood S, Hossein Golfeshan A, Tabatabaei M, Salehi Jouzani G, Najafi GH, Gholami M, Ardjmand M (2013) Lignocellulosic biomass to bioethanol, a comprehensive review with a focus on pretreatment. Renew Sustain Energy Rev 27:77-93. https://doi.org/10.1016/j.rser.2013.06.033

27. Zhou Z, Lei F, Li P, Jiang J (2018) Lignocellulosic biomass to biofuels and biochemicals: a comprehensive review with a focus on ethanol organosolv pretreatment technology. Biotechnol Bioeng 115(11):2683-2702. https://doi.org/10.1002/ bit. 26788

28. Araque E, Parra C, Freer J, Contreras D, Rodríguez J, Mendonça R, Baeza J (2008) Evaluation of organosolv pretreatment for the conversion of Pinus radiata D. Don to ethanol Enzyme Microb Technol 43(2):214-219. https://doi.org/10.1016/j.enzmictec. 2007.08.006

29. Badiei M, Asim N, Jahim JM, Sopian K (2014) Comparison of chemical pretreatment methods for cellulosic biomass. APCBEE Proc 9:170-174. https://doi.org/10.1016/j.apcbee.2014.01.030

30. Li M, Tu M, Cao D, Bass P, Adhikari S (2013) Distinct roles of residual xylan and lignin in limiting enzymatic hydrolysis of organosolv pretreated Loblolly pine and Sweetgum. J Agric Food Chem 61(3):646-654. https://doi.org/10.1021/jf304517w

31. Nakagame S, Chandra RP, Saddler JN (2010) The effect of isolated lignins, obtained from a range of pretreated lignocellulosic substrates, on enzymatic hydrolysis. Biotechnol Bioeng 105(5):871-879. https://doi.org/10.1002/bit.22626

32. Pan X, Arato C, Gilkes N, Gregg D, Mabee W, Pye K, Xiao Z, Zhang X, Saddler J (2005) Biorefining of softwoods using ethanol organosolv pulping: preliminary evaluation of process streams for manufacture of fuel-grade ethanol and co-products. Biotechnol Bioeng 90(4):473-481. https://doi.org/10.1002/bit. 20453

33. Parajo JC, Alonso JL, Santos V (1995) Kinetics of catalysed organosolv processing of pine wood. Ind Eng Chem Res 34:4333-4342. https://doi.org/10.1021/ie00039a025

34. Vázquez G, Antorrena G, González J, Freire S, López S (1997) Acetosolv pulping of pine wood. Kinetic modelling of lignin solubilization and condensation. Bioresour Technol 59(2):121-7. https://doi.org/10.1016/S0960-8524(96)00168-X

35. Shahbazi A, Li Y, Mims MR (2005) Application of sequential aqueous steam treatments to the fractionation of softwood. Appl Biochem Biotechnol 124(1):973-987. https://doi.org/10.1385/ ABAB:124:1-3:0973

36. Sun S, Sun S, Cao X, Sun R (2016) The role of pretreatment in improving the enzymatic hydrolysis of lignocellulosic materials. Bioresour Technol 199:49-58. https://doi.org/10.1016/j.biortech. 2015.08.061

37. Yáñez-S M, Matsuhiro B, Nuñez C, Pan S, Hubbell CA, Sannigrahi P, Ragauskas AJ (2014) Physicochemical characterization of ethanol organosolv lignin (EOL) from Eucalyptus globulus: effect of extraction conditions on the molecular structure. Polym Degrad Stab 110:184-194. https://doi.org/10.1016/j.polymdegra dstab.2014.08.026

38. Parot M, Rodrigue D, Stevanovic T (2022) High purity softwood lignin obtained by an eco-friendly organosolv process. Bioresour Technol Rep 17:100880. https://doi.org/10.1016/j.biteb.2021. 100880

39. Rinaldi R, Jastrzebski R, Clough MT, Ralph J, Kennema M, Bruijnincx PCA, Weckhuysen BM (2016) Paving the way for lignin valorisation: recent advances in bioengineering, biorefining and catalysis. Angew Chem Int Ed 55(29):8164-8215. https://doi. org/10.1002/anie.201510351

40. McGee JK, April GC (1982) Chemicals from renewable resources: hemicellulose behavior during organosolv delignification of southern yellow pine. Chem Eng Commun 19:49-56. https://doi.org/10.1080/00986448208956327

41. Del Rio LF, Chandra RP, Saddler JN (2010) The effect of varying organosolv pretreatment chemicals on the physicochemical properties and cellulolytic hydrolysis of mountain pine beetle-killed lodgepole pine. Appl Biochem Biotechnol 161(1):1-21. https:// doi.org/10.1007/s12010-009-8786-6

42. De Santi A, Galkin M, Lahive C, Deuss P, Barta K (2019) Effective lignin-first fractionation of softwood lignocellulose using a mild dimethyl carbonate organosolv process. ChemRxiv https:// doi.org/10.26434/chemrxiv.10310945.v1

43. Todaka M, Kowhakul W, Masamoto H et al (2019) Delignification of softwood by glycerol from biodiesel by-product I: model reaction using glycerol and fatty acid sodium soap mixture for pretreatment on bioethanol production. J Wood Sci 65:49. https:// doi.org/10.1186/s10086-019-1829-x

44. Hundt M, Schnitzlein K, Schnitzlein MG (2013) Alkaline polyol pulping and enzymatic hydrolysis of softwood: effect of pulping severity and pulp properties on cellulase activity and overall sugar yield. Bioresour Technol 134:307-315. https://doi.org/10. 1016/j.biortech.2013.02.018

45. Schuerch C (1952) The solvent properties of liquids and their relation to the solubility, swelling, isolation and fractionation of lignin. J Am Chem Soc 74(20):5061-5067. https://doi.org/10. 1021/ja01140a020

46. Hansen CM, Björkman A (1998) The ultrastructure of wood from a solubility parameter point of view. Holzforschung 52(4):335344. https://doi.org/10.1515/hfsg.1998.52.4.335

47. Achinivu EC, Mohan M, Choudhary H, Das L, Huang K, Magurudeniya HD et al (2021) A predictive toolset for the identification of effective lignocellulosic pretreatment solvents: a case study of solvents tailored for lignin extraction. Green Chem. https://doi.org/10.1039/D1GC01186C

48. Hansen CM (2007) Hansen solubility parameters, 2nd edn (2007). CRC Press, Boca Raton

49. Ni Y, Hu Q (1995) Alcell® lignin solubility in ethanol-water mixtures. J Appl Polym Sci 57(12):1441-1446. https://doi.org/ 10.1002/app.1995.070571203 
50. Sannigrahi P, Ragauskas AJ (2013) Fundamentals of biomass pretreatment by fractionation. Aqueous pretreatment of plant biomass for biological and chemical conversion to fuels and chemicals. John Wiley \& Sons, New Jersey pp 201-22.

51. Amiri H, Karimi K (2016) Integration of autohydrolysis and organosolv delignification for efficient acetone, butanol, and ethanol production and lignin recovery. Ind Eng Chem Res 55(17):4836-4845. https://doi.org/10.1021/acs.iecr.6b00110

52. Abdou Alio M, Tugui O-C, Vial C, Pons A (2019) Microwaveassisted organosolv pretreatment of a sawmill mixed feedstock for bioethanol production in a wood biorefinery. Bioresour Technol 276:170-176. https://doi.org/10.1016/j.biortech.2018.12.078

53. Agnihotri S, Johnsen IA, Bøe MS, Øyaas K, Moe S (2015) Ethanol organosolv pretreatment of softwood (Picea abies) and sugarcane bagasse for biofuel and biorefinery applications. Wood Sci Technol 49(5):881-896. https://doi.org/10.1007/ s00226-015-0738-4

54. Pan X, Gilkes N, Saddler JN (2006) Effect of acetyl groups on enzymatic hydrolysis of cellulosic substrates. Holzforschung 60(4):398-401. https://doi.org/10.1515/HF.2006.062

55. Bernal-Lugo I, Jacinto-Hernández C, Gimeno M, Montiel C, Rivero-Cruz F, Velasco O (2019) Highly efficient single-step pretreatment to remove lignin and hemicellulose from softwood. Bioresources 14:3567-77. https://doi.org/10.15376/biores.14.2. 3567-3577

56. Moreira R, Mendes CV, Banaco MBF, Carvalho MGV, Portugal A (2020) New insights in the fractionation of Pinus pinaster wood: sequential autohydrolysis, soda ethanol organosolv and acidic precipitation. Ind Crops Prod 152:112499. https://doi.org/ 10.1016/j.indcrop.2020.112499

57. Muñoz C, Mendonça R, Baeza J, Berlin A, Saddler J, Freer J (2007) Bioethanol production from bio- organosolv pulps of Pinus radiata and Acacia dealbata. J Chem Technol Biotechnol 82(8):767-774. https://doi.org/10.1002/jctb.1737

58. Fissore A, Carrasco L, Reyes P, Rodríguez J, Freer J, Mendonça RT (2010) Evaluation of a combined brown rot decay-chemical delignification process as a pretreatment for bioethanol production from Pinus radiata wood chips. J Ind Microbiol Biotechnol 37(9):893-900. https://doi.org/10.1007/s10295-010-0736-3

59. Matsakas L, Raghavendran V, Yakimenko O, Persson G, Olsson E, Rova U, Olsson L, Christakopoulos P (2019) Lignin-first biomass fractionation using a hybrid organosolv - Steam explosion pretreatment technology improves the saccharification and fermentability of spruce biomass. Bioresour Technol 273:521-528. https://doi.org/10.1016/j.biortech.2018.11.055

60. Kalogiannis KG, Karnaouri A, Michailof C, Tzika AM, Asimakopoulou G, Topakas E, Lappas AA (2020) OxiOrganosolv: a novel acid free oxidative organosolv fractionation for lignocellulose fine sugar streams. Bioresour Technol 313:123599. https:// doi.org/10.1016/j.biortech.2020.123599

61. Abdou Alio M, Tugui O-C, Rusu L, Pons A, Vial C (2020) Hydrolysis and fermentation steps of a pretreated sawmill mixed feedstock for bioethanol production in a wood biorefinery. Bioresour Technol 310:123412. https://doi.org/10.1016/j.biortech. 2020.12341245

62. Vedoya CI, Vallejos ME, Area MC, Felissia FE, Raffaeli N, da Silva Curvelo AA (2020) Hydrothermal treatment and organosolv pulping of softwood assisted by carbon dioxide. Ind Crops Prod 147:112244. https://doi.org/10.1016/j.indcrop.2020.112244

63. Tu M, Zhang X, Paice M, MacFarlane P, Saddler JN (2009) The potential of enzyme recycling during the hydrolysis of a mixed softwood feedstock. Bioresour Technol 100(24):6407-6415. https://doi.org/10.1016/j.biortech.2009.06.108

64. Hideno A, Kawashima A, Endo T, Honda K, Morita M (2013) Ethanol-based organosolv treatment with trace hydrochloric acid improves the enzymatic digestibility of Japanese cypress
(Chamaecyparis obtusa) by exposing nanofibers on the surface. Bioresour Technol 132:64-70. https://doi.org/10.1016/j.biortech. 2013.01.048

65. Berlin A, Gilkes N, Kilburn D, Bura R, Markov A, Skomarovsky A et al (2005) Evaluation of novel fungal cellulase preparations for ability to hydrolyze softwood substrates - evidence for the role of accessory enzymes. Enzyme Microb Technol 37(2):175184. https://doi.org/10.1016/j.enzmictec.2005.01.039

66. Chabbert B, Terryn C, Herbaut M, Vaidya A, Habrant A, Paës G, Donaldson L (2018) Fluorescence techniques can reveal cell wall organization and predict saccharification in pretreated wood biomass. Ind Crops Prod 123:84-92. https://doi.org/10.1016/j. indcrop.2018.06.058

67. Newman RH, Vaidya AA, Campion SH (2013) A mathematical model for the inhibitory effects of lignin in enzymatic hydrolysis of lignocellulosics. Bioresour Technol 130:757-762. https://doi. org/10.1016/j.biortech.2012.12.122

68. Nakagame S, Chandra RP, Kadla JF, Saddler JN (2011) The isolation, characterization and effect of lignin isolated from steam pretreated Douglas-fir on the enzymatic hydrolysis of cellulose. Bioresour Technol 102(6):4507-4517. https://doi. org/10.1016/j.biortech.2010.12.082

69. Chandra RP, Ewanick SM, Chung PA, Au-Yeung K, Rio LD, Mabee W, Saddler JN (2009) Comparison of methods to assess the enzyme accessibility and hydrolysis of pretreated lignocellulosic substrates. Biotechnol Lett 31(8):1217-1222. https:// doi.org/10.1007/s10529-009-9993-5

70. Del Rio LF, Chandra RP, Saddler JN (2012) Fibre size does not appear to influence the ease of enzymatic hydrolysis of organosolv-pretreated softwoods. Bioresour Technol 107:235-242. https://doi.org/10.1016/j.biortech.2011.12.057

71. Bouxin FP, David Jackson S, Jarvis MC (2014) Organosolv pretreatment of Sitka spruce wood: conversion of hemicelluloses to ethyl glycosides. Bioresour Technol 151:441-444. https://doi.org/10.1016/j.biortech.2013.10.105

72. Donaldson L, Vaidya A (2017) Visualising recalcitrance by colocalisation of cellulase, lignin and cellulose in pretreated pine biomass using fluorescence microscopy. Sci Rep 7(1):44386. https://doi.org/10.1038/srep44386

73. Lesar B, Humar M, Hora G, Hachmeister P, Schmiedl D, Pindel E, Siika-aho M, Liitiä T (2016) Utilization of recycled wood in biorefineries: preliminary results of steam explosion and ethanol/water organosolv pulping without a catalyst. Eur J Wood Wood Prod 74(5):711-723. https://doi.org/10.1007/ s00107-016-1064-8

74. Lynd LR, Weimer PJ, Zyl WHv, Pretorius IS, (2002) Microbial cellulose utilization: fundamentals and biotechnology. Microbiol Mol Biol Rev 66(3):506-577. https://doi.org/10.1128/MMBR. 66.3.506-577.2002

75. Sinha A, Martin EM, Lim KT, Carrier DJ, Han H, Zharov VP, Kim JW (2015) Cellulose nanocrystals as advanced "green" materials for biological and biomedical engineering. J Biosyt Eng 40:373-393. https://doi.org/10.5307/JBE.2015.40.4.373

76. Santos RB, Hart P, Jameel H, Chang H-m (2013) Wood based lignin reactions important to the biorefinery and pulp and paper industries. BioResources 8(1):22. https://doi.org/10.15376/ biores.8.1.1456-1477

77. Ma X, Yang X, Zheng X, Chen L, Huang L, Cao S, Akinosho $\mathrm{H}$ (2015) Toward a further understanding of hydrothermally pretreated holocellulose and isolated pseudo lignin. Cellul 22(3):1687-1696. https://doi.org/10.1007/s10570-015-0607-1

78. Sipponen MH, Rahikainen J, Leskinen T, Pihlajaniemi V, Mattinen M-L, Lange H, Crestini C, Österberg MÖ (2017) Structural changes of lignin in biorefinery pretreatments and consequences to enzyme-lignin interactions. Nordic Pulp Pap Res J 
32(4):550-571. https://doi.org/10.3183/npprj-2017-32-04_p550571_sipponen

79. Del Rio LF, Chandra RP, Saddler JN (2011) The effects of increasing swelling and anionic charges on the enzymatic hydrolysis of organosolv-pretreated softwoods at low enzyme loadings. Biotechnol Bioeng 108(7):1549-1558. https://doi.org/10.1002/ bit. 23090

80. Lai C, Tu M, Shi Z, Zheng K, Olmos LG, Yu S (2014) Contrasting effects of hardwood and softwood organosolv lignins on enzymatic hydrolysis of lignocellulose. Bioresour Technol 163:320-327. https://doi.org/10.1016/j.biortech.2014.04.065

81. Huang Y, Sun S, Huang C, Yong Q, Elder T, Tu M (2017) Stimulation and inhibition of enzymatic hydrolysis by organosolv lignins as determined by zeta potential and hydrophobicity. Biotechnol Biofuels 10(1):162. https://doi.org/10.1186/ s13068-017-0853-6

82. Podschun J, Stücker A, Saake B, Lehnen R (2015) Structurefunction relationships in the phenolation of lignins from different sources. ACS Sustain Chem Eng 3:2526-2532. https://doi.org/ 10.1021/acssuschemeng.5b00705

83. Wang M, Leitch M, Xu CC (2009) Synthesis of phenolformaldehyde resol resins using organosolv pine lignins. Eur Polym $\mathbf{J}$ 45(12):3380-3388. https://doi.org/10.1016/j.eurpolymj.2009.10. 003

84. Harmita H, Karthikeyan KG, Pan X (2009) Copper and cadmium sorption onto kraft and organosolv lignins. Bioresour Technol 100:6183-6191. https://doi.org/10.1016/j.biortech.2009.06.093

85. Gordobil O, Egüés I, Labidi J (2016) Modification of eucalyptus and spruce organosolv lignins with fatty acids to use as filler in PLA. React Funct Polym 104:45-52. https://doi.org/10.1016/j. reactfunctpolym.2016.05.002

86. Gordobil O, Moriana R, Zhang L, Labidi J, Sevastyanova O (2016) Assesment of technical lignins for uses in biofuels and biomaterials: structure-related properties, proximate analysis and chemical modification. Ind Crops Prod 83:155-165. https://doi. org/10.1016/j.indcrop.2015.12.048

87. Løhre C, Kleinert M, Barth T (2017) Organosolv extraction of softwood combined with lignin-to-liquid-solvolysis as a semicontinuous percolation reactor. Biomass Bioenergy 99:147-155. https://doi.org/10.1016/j.biombioe.2017.02.014

88. Jönsson LJ, Martín C (2016) Pretreatment of lignocellulose: formation of inhibitory by-products and strategies for minimizing their effects. Bioresour Technol 199:103-112. https://doi.org/10. 1016/j.biortech.2015.10.009

89. Hansen NML, Plackett D (2008) Sustainable films and coatings from hemicelluloses: a review. Biomacromol 9(6):1493-1505. https://doi.org/10.1021/bm800053z

90. Price NPJ, Hartman TM, Faber TA, Vermillion KE, Fahey GC Jr (2011) Galactomannan oligosaccharides (CGMO) from a molasses byproduct of pine (Pinus taeda) fiberboard production. J Agric Food Chem 59:1854-1861. https://doi.org/10.1021/jf103 7097

91. Arato C, Pye EK, Gjennestad G (2005) The lignol approach to biorefining of woody biomass to produce ethanol and chemicals.
Appl Biochem Biotechnol 123(1):871-882. https://doi.org/10. 1385/ABAB:123:1-3:0871

92. Kangas H, Tamminen T, Liitiä T, Hakala T, Vorwerg W, PoppiusLevlin K (2014) Lignofibre (LGF) process - a flexible biorefinery for lignocellulosics. Cellul Chem Technol 48:765-71. http:// www.cellulosechemtechnol.ro/pdf/CCT9-10(2014)/p.765-771. pdf

93. Katzen R, Frederickson R, Brush BF (1980) Alcohol pulping and recovery process. Chem Eng Prog 76:62-67

94. Koncel J (1991) Alcell pulping process moves to first commercial installation. Am Papermak 54:22-26

95. Pye E, Lora J (1991) The ALCELL process-a proven alternative to kraft pulping. Tappi J 74:113-118

96. Farías-Sánchez JC, López-Miranda J, Castro-Montoya AJ, Saucedo-Luna J, Carrillo-Parra A, López-Albarrán P, PinedaPimentel MG, Rutiaga-Quiñones JG (2015) Comparison of five pretreatments for the production of fermentable sugars obtained from Pinus pseudostrobus L. wood. EXCLI J 14:430-8. https:// doi.org/10.17179/excli2014-613

97. Monrroy M, Ibañez J, Melin V, Baeza J, Mendonça RT, Contreras D, Freer J (2010) Bioorganosolv pretreatments of $P$. radiata by a brown rot fungus (Gloephyllum trabeum) and ethanolysis. Enzyme Microb Technol 47(1):11-6. https://doi.org/10.1016/j. enzmictec.2010.01.009

98. Matsakas L, Nitsos C, Vörös D, Rova U, Christakopoulos P (2017) High-titer methane from organosolv-pretreated Spruce and Birch. Energies 10(3):263. https://doi.org/10.3390/en100 30263

99. Mabee WE, Gregg DJ, Arato C, Berlin A, Bura R, Gilkes N et al (2006) Updates on softwood-to-ethanol process development. Appl Biochem Biotechnol 129(1):55-70. https://doi.org/10.1385/ ABAB:129:1:55

100. Kurabi A, Berlin A, Gilkes N, Kilburn D, Bura R, Robinson J et al (2005) Enzymatic hydrolysis of steam-exploded and ethanol organosolv-pretreated Douglas-Fir by novel and commercial fungal cellulases. In: Davison BH, Evans BR, Finkelstein M, McMillan JD (eds) Twenty-Sixth Symposium on Biotechnology for Fuels and Chemicals. Humana Press, Totowa, NJ, pp 219-230

101. Kim Y, Yu A, Han M, Choi G-W, Chung B (2010) Ethanosolv pretreatment of barley straw with iron(III) chloride for enzymatic saccharification. J Chem Technol Biotechnol 85(11):1494-1498. https://doi.org/10.1002/jctb.2455

102. Yang X, Cui C, Zheng A, Zhao Z, Wang C, Xia S, Huang Z, Wei G, Li H (2020) Ultrasonic and microwave assisted organosolv pretreatment of pine wood for producing pyrolytic sugars and phenols. Ind Crops Prod 157:112921. https://doi.org/10.1016/j. indcrop.2020.112921

Publisher's note Springer Nature remains neutral with regard to jurisdictional claims in published maps and institutional affiliations. 